\title{
PENYUSUNAN DAN VALIDASI SKALA PAKET-H (HAPPINESS)
}

\author{
Dary les Shabrina, Hasna Fadillah Sustring, Mayang Sari, \\ Nur Baity Ulya Shabrina, dan Nurmala Zakir \\ Program Studi Magister Psikologi Profesi, Universitas Islam Indonesia, Yogyakarta \\ E-mail: deryies@gmail.com
}

\begin{abstract}
Abstrak
Magister Profesi Psikologi merupakan peminatan atau jenjang pendidikan magister psikologi, dimana pesertanya dipersiapkan untuk memiliki kompetensi sebagai seorang psikolog. Perkuliahan yang sangat padat membuat mahasiswa harus pintar-pintar mengatur waktu dan peduli dengan kesehatannya supaya dapat mengikuti proses kuliah dan bahagia menjalani perkuliahan. Tujuan dari penelitian ini adalah merancang sebuah alat ukur untuk mengetahui tingkat kebahagiaan mahasiswa yang menempuh pendidikan magister profesi psikologi. Penelitian ini menggunakan metode Validasi skala dengan menggunakan Exploratory Factor Analysis (EFA). Skala dirancang berdasarkan teori kebahagiaan Seligman (2005) dan 'Aidh al-Qarni, (2004). Hasil analisis menunjukkan skala kepahagiaan yang disusun peneliti terdiri dari 5 faktor dengan 28 aitem setelah dianalisis diperoleh 4 faktor dengan 23 aitem.
\end{abstract}

Kata Kunci : Kebahagiaan, Mahasiswa Magister Psikologi Profesi

\section{DEVELOPMENT AND VALIDATION OF THE H-PACKAGE SCALE (HAPPINESS)}

\begin{abstract}
The Masters in Professional Psychology is a specialization or a master's degree in psychology education, where participants are prepared to have competence as a psychologist. Lectures that are very dense make students have to be smart to manage their time and care about their health so they can follow the lecture process and be happy in their lectures. The purpose of this study is to design a measuring tool to determine the level of happiness of students who take the Masters in Psychology Profession. This study uses a scale validation method using Exploratory Factor Analysis (EFA). The scale was designed based on the happiness theory of Seligman (2005) and 'Aidh al-Qarni, (2004). The analysis showed that the scale of happiness compiled by researchers consisted of 5 factors with 28 items after analysis, 4 factors with 23 items were obtained.
\end{abstract}

Keywords :Happiness, Professional Psychology Masters Student 


\section{Pendahuluan}

Psikologi merupakan salah satu jurusan yang semakin lama semakin meningkat setiap peminatnya tahunnya. Selain tingkat strata 1 , jurusan psikologi memiliki jenjang studi Magister Profesi, yaitu proses untuk menjadi seorang psikolog melalui studi Magister Psikologi dan Profesi Psikologi. Program ini mulai menarik minat para mahasiswa pada era tahun 2000an yang sebelumnya masyarakat hanya mengenal psikiater (Kusmawardhani, 2017).

Magister Profesi Psikologi merupakan peminatan atau jenjang pendidikan magister psikologi, dimana pesertanya dipersiapkan untuk memiliki kompetensi sebagai seorang psikolog. Dengan mengikuti program magister profesi, calon psikolog setelah selesai menempuh study akan mendapatkan surat ijin praktek psikologi atau SIPP, dan berhak untuk membuka praktek psikologi. Berdasarkan penjelasan Pedoman Umum Kode Etik Psikologi Indonesia (2010), Psikolog merupakan Iulusan pendidikan profesi yang berkaitan dengan praktik psikologi atau layanan psikologi yang meliputi bidang bidang praktik klinis dan konseling. Untuk menjadi psikolog, mahasiswa perlu mengikuti serangkaian kegiatan perkuliahan yang ditempuh kurang lebih dua sampai tiga tahun masa studi dengan tugas akhir laporak Praktik Kerja Psikologi Profesi (PKPP) dan laporan penelitian (Tesis).

Alhaque (2017) menceritakan pengalamannya ketika menempuh kuliah Profesi psikologi di UNPAD. Pada semester pertama perkuliahan Alhaque mengikuti serangkaian kegiatan perkuliahan yang dimana matakuliah keprofesian dan kemagisteran berjalan beriringan. Kegiatannya memang sangat padat selama semester satu ini. Perkuliahan yang penuh setiap minggunya, dari pagi hingga sore, bahkan terkadang sampai malam. Selain itu, sepulang kuliah akan ada tugas-tugas yang perlu dikerjakan atau disiapkan untuk pertemuan selanjutnya. Selama masa matrikulasi dan semester, Alhaque sering menghabiskan waktu hingga pukul 03.00 malam untuk mengerjakan tugas atau belajar bersama teman. Meskipun padat dan melelahkan, namun masa-masa matrikulasi dan semester satu merupakan masa yang paling menyenangkan dan menggugah daya pikir serta semangat sebagai seorang pelajar. Untuk itu, dalam menjalani perkuliahan harus menikmati prosesnya semaksimal mungkin, dengan begitu proses perkuliahan akan menjadi rangkaian kegiatan yang menyenangkan. Selain itu gunakan waktu luang untuk tetap bersenang-senang dan menikmati hidup yang berguna untuk menciptakan kebahagiaan dalam menjalani aktifitas menjadi mahasiswa.

Sejalan dengan hasil wawancara yang kami lakukan pada dua orang mahasiswa yang magister psikologi profesi di universitas $X$. Mahasiswi berinisial Y menjelaskan bahwa ternyata perkuliahan yang sudah dilakukan beberapa bulan terakhir ini sangat menguras tenaga dan pikiran. Sempat merasa jenuh dengan rutinitas yang begitu padat dengan selalu mengharapkan waktu untuk libur atau pulang ke kampung halaman. Butuh motivasi dari diri dan lingkungan untuk bertahan mengikuti proses perkuliahan, karena untuk mencapai tujuan awal menjadi seorang psikolog butuh perjuangan pada prosesnya. Begitupun yang dirasakan oleh mahasiswa berinisial Z, ketika diwawancara dia mengatakan bahwa mengikuti perkuliahan magister psikologi profesi adalah proses yang berat. Membutuhkan kelapangan hati dan sabar dalam menjalankan prosesnya. Karena prosesnya yang tidak mudah, maka sejak awal sebelum perkuliahan mahasiswa Z mengatakan sudah mempersiapkan diri untuk segala 
tekanan yang ada dalam kegiatan perkuliahan. Mahasiswa Z sadar akan konsekuensinya ketika mengikuti perkuliahan magister psikologi profesi untuk mencapai gelar profesi psikolog.

Perkuliahan yang sangat padat seperti yang diceritakan diatas membuat mahasiswa harus pintarpintar mengatur waktu dan peduli dengan kesehatannya supaya dapat mengikuti proses kuliah dan tetap bahagia dalam menjalani kehidupan perkuliahan. Bahagia menurut Seligman (2005) menejelaskan kebahagiaan adalah emosi positif yang melibatkan emosi positif masa lalu masa sekarang dan masa depan. Emosi positif yang ditujukan pada masa lalu meliputi perasan lega, kedamaian, kesuksesan; emosi masa sekarang melibatkan kenikmatan yang didapatkan dari akifitas-aktifitas dan membuat individu terlibat penuh dalam aktifitas tersebut; sedangkan emosi positif dimasa depan melibatkan optimisme, harapan, kepercayaan, keyakinan dan kepastian.

Kebahagiaan menurut Seligman (2005) menejelaskan kebahagiaan adalah emosi positif yang melibatkan emosi positif masa lalu masa sekarang dan masa depan. Emosi positif yang ditujukan pada masa lalu meliputi perasan lega, kedamaian, kesuksesan ; emosi masa sekarang melibatkan kenikmatan yang didapatkan dari akifitas-aktifitas dan membuat individu terlibat penuh dalam aktifitas tersebut; sedangkan emosi positif dimasa depan melibatkan optimisme, harapan, kepercayaan, keyakinan dan kepastian. Berikut adalah faktor-faktor ekternal yang mempengaruhi kebahagiaan seseorang, yaitu:

1) Budaya

Triandis (Carr, 2004) mengatakan bahwa faktor budaya dan sosial politik berperan dalam tingkat kebahagiaan seseorang.

2) Kehidupan Sosial

Menurut Seligman (2005), orang yang sangat bahagia menjalani kehidupan sosial yang kaya dan memuaskan, paling sedikit menghabiskan waktu sendirian dan mayoritas dari mereka bersosialisasi.

3) Agama atau Religiusitas

Orang yang religius lebih bahagia dan lebih puas terhadap kehidupan daripada orang yang tidak religius. Hal ini dikarenakan agama memberikan harapan akan masa depan dan menciptakan makna dalam hidup bagi manusia (Seligman, 2005).

4) Pernikahan

Seligman (2005) mengatakan bahwa pernikahan sangat erat hubungannya dengan kebahagiaan.

5) Usia

Kepuasan hidup sedikit meningkat sejalan dengan bertambahnya usia, afek positif sedikit melemah, dan afek negatif tidak berubah menjelaskan hal yang berubah ketika seseorang menua adalah intensitas emosi dimana perasaan "mencapai puncak dunia" dan "terpuruk dalam keputusasaan" berkurang seiring dengan bertambahnya umur dan pengalaman (Seligman, 2005).

6) Uang

Seligman (2005) menjelaskan bahwa di Negara yang sangat miskin, kaya bisa berarti lebih bahagia. Namun di Negara yang lebih makmur dimana hampir semua orang memperoleh kebutuhan dasar, peningkatan kekayaan tidak begitu berdampak pada kebahagiaan (Seligman, 2005).

7) Kesehatan

Kesehatan objektif yang baik tidak begitu berkaitan dengan kebahagiaan. Menurut Seligman (2005) 
yang penting adalah persepsi subjektif kita terhadap seberapa sehat diri kita.

8) Jenis Kelamin

Jenis kelamin memiliki hubungan yang tidak konsisten dengan kebahagiaan. Wanita memiliki kehidupan emosional yang lebih ekstrim daripada pria (Seligman, 2005). Wanita mengalami lebih banyak emosi positif dengan intensitas yang lebih tinggi dibandingkan pria. Seligman (2005) juga menjelaskan bahwa tingkat emosi rata-rata pria dan wanita tidak berbeda namun wanita lebih bahagia dan juga lebih sedih daripada pria.

Menurut Seligman (2005) lima aspek utama yang dapat menjadi sumber kebahagiaan sejati, yaitu : a) Hubungan positif atau positive relationship bukan sekedar memiliki teman, pasangan, ataupun anak, tetapi dengan menjalin hubungan yang positif dengan individu yang ada disekitar. Status perkawinan dan kepemilikan anak tidak dapat menjamin kebahagiaan seseorang. b) Keterlibatan penuh bukan hanya pada karir, tetapi juga dalam aktivitas lain seperti hobby dan aktivitas bersama keluarga. Dengan melibatkan diri secara penuh, bukan hanya fisik yang beraktivitas, tetapi hati dan pikiran juga turut serta dalam aktivitas tersebut. c) Penemuan makna dalam keseharian dalam keterlibatan penuh dan hubungan positif dengan orang lain tersirat satu cara lain untuk dapat bahagia, yakni menemukan makna dalam apapun yang dilakukan. d) Optimisme yang realistis, orang yang optimis ditemukan lebih berbahagia. Mereka tidak mudah cemas karena menjalani hidup dengan penuh harapan. e) Resiliensi terahadap kesedihan menjadi kebahagian. Selain itu terdapat juga tiga faktor internal yang berkontribusi terhadap kebahagiaan, yaitu : a) Kepuasan Terhadap Masa Lalu Kepuasan terhadap masa lalu dapat dicapai melalui tiga cara: Melepaskan pandangan masa lalu sebagai penentu masa depan seseorang.

b) Gratitude (bersyukur) terhadap hal-hal baik dalam hidup akan meningkatkan kenangan-kenangan positif. c) Forgiving dan forgetting (memaafkan dan melupakan) Perasaan seseorang terhadap masa lalu tergantung sepenuhnya pada ingatan yang dimilikinya. Salah satu cara untuk menghilangkan emosi negatif mengenai masa lalu adalah dengan memaafkan. Defenisi memaafkan menurut Affinito (dalam Seligman, 2002) adalah memutuskan untuk tidak menghukum pihak yang menurut seseorang telah berlaku tidak adil padanya, bertindak sesuai dengan keputusan tersebut dan mengalami kelegaan emosi setelahnya. Memaafkan dapat menurunkan stress dan meningkatkan kemungkinan terciptanya kepuasan hidup. d) Optimisme Terhadap Masa Depan optimisme didefinisikan sebagai ekspektasi secara umum bahwa akan terjadi lebih banyak hal baik dibandingkan hal buruk di masa yang akan datang (Carr, 2004). e) Kebahagiaan Pada Masa Sekarang Kebahagiaan masa sekarang melibatkan dua hal, yaitu: Pleasure yaitu kesenangan yang memiliki komponen sensori dan emosional yang kuat, sifatnya sementara dan melibatkan sedikit pemikiran. Pleasure terbagi menjadi dua, yaitu bodily pleasures yang didapat melalui indera dan sensori, dan higher pleasures yang didapat melalui aktivitas yang lebih kompleks. Ada tiga hal yang dapat meningkatkan kebahagiaan sementara, yaitu menghindari habituasi dengan cara memberi selang waktu cukup panjang antar kejadian menyenangkan; savoring (menikmati) yaitu menyadari dan dengan sengaja memperhatikan sebuah kenikmatan; serta mindfulness (kecermatan) yaitu mencermati dan menjalani segala pengalaman dengan tidak terburu-buru dan melalui perspektif yang berbeda. f) Gratification yaitu kegiatan yang sangat disukai oleh seseorang namun tidak selalu melibatkan perasaan tertentu, dan durasinya lebih lama dibandingkan pleasure, kegiatan yang memunculkan gratifikasi umumnya memiliki komponen seperti menantang, 
membutuhkan keterampilan dan konsentrasi, bertujuan, ada umpan balik langsung, pelaku tenggelam di dalamnya, ada pengendaian, kesadaran diri pupus, dan waktu seolah berhenti.

Menurut 'Aidh al-Qarni, (2004) pemikir muslim kontemporer bahwa kebahagiaan adalah keringanan hati karena kebenaran yang dihayatinya, kebahagiaan adalah kelapangan dada karena prinsip yang menjadi pedoman hidup, dan kebahagiaan adalah ketenangan hati karena kebaikan disekelilingnya.

Kebahagiaan adalah afeksi positif yang dimiliki individu untuk menerima dengan positif setiap proses dalam mencapai tujuan sesuai dengan pedoman hidup yang diyakini sehingga individu merasa puas dengan kehidupannya.

Selanjutnya, berdasarkan pembahasan di atas, peneliti melihat telah banyak alat ukur yang mengukur kebahagiaan individu tetapi belum ada yang spesifik mengukur kebahagiaan pada mahasiswa Magister Psikologi Profesi.

Olehnya, tujuan dari penelitian ini yaitu peneliti mengembangkan sendiri alat ukur kebahagiaan pada mahasiswa Magister Psikologi Profesi lalu melihat seberapa valid dan reliabel alat ukur yang dikembangkan peneliti untuk menjelaskan konstruk tersebut.

Mengacu dari penjelasan teori yang telah dijabarkan, maka dapat disimpulkan kebahagiaan adalah afeksi positif yang dimiliki individu untuk menerima dengan positif setiap proses dalam mencapai tujuan sesuai dengan pedoman hidup yang diyakini sehingga individu merasa puas dengan kehidupannya.

\section{Metode}

Variable Penelitian

Variable pada penelitian ini adalah happiness atau kebahagiaan. Skala dikembangkan berdasarkan teori kebahagiaan dari Saligman (2005) dan kebahagiaan 'Aidh al-Qarni (2004).

\section{Subjek Penelitian}

Responden penelitian sebanyak 122 orang mahasiswa Magister Psikologi Profesi yang sedang menjalani proses perkuliahan di Indonesia.

\section{Desain Penelitian}

Desain penelitian yang digunakan adalah validasi skala kebahagiaan yang kembangkan oleh peneliti. Peneliti mendesain 4 dimensi skala kebahagiaan ke dalam bentuk alat ukur sebaran pernyataan.

\section{Prosedur dan Analisis Data}

Pada penelitian ini, skala yang dikembangkan peneliti divalidasi oleh satu orang expert judgement yaitu dosen mata kuliah ini, lalu setelah dianggap valid dilanjutkan dengan memnyebarkan skala ke responden.

Adapun analisis data yang digunakan yaitu analisis faktor dengan Exploratory Factor Analysis (EFA). Teknik analisis data dengan eksploratori faktor bertujuan untuk melihat sejauh mana ketepatan atau kecermatan alat ukur kebahagiaan untuk mengukur kebahagiaan mahasiswa Magister Psikologi Profesi berdasarkan data empiris yang telah diperoleh dari pengisian skala. 


\section{Hasil dan diskusi}

Penelitian ini melalui analisis faktor eksplorasi dengan tahapan yaitu memilih variabel untuk membentuk faktor, mengekstrasi faktor, rotasi faktor, dan memberikan nama faktor baru. Pada tahapan pertama dalam analisis ini yaitu memilih variabel untuk membentuk faktor. Berdasarkan tabel di bawah ini, diketahui nilai KMO sebesar 0,825 dan memenuhi kaidah $p>0,5$ yang berarti kecukupan sampling pada data ini terpenuhi dan kecukupan sampling ini berada pada kategori sedang. Nilai signifikansi dapat diketahui sebesar 0,000 atau $p<0,05$ yang berarti instrument pada penelitian ini valid.

Pada kolom korelasi anti-image, terdapat 1 aitem yang tidak memiliki nilai kelayakan untuk dilakukan analisis faktor karena mempunyai koefisien korelasi anti-image dibawah $0,5(p<0,5)$ yaitu aitem $\mathrm{H} 2$. Adapun nilai masing-masing aitem yang memiliki nilai MSA diatas 0,5 adalah sebagai berikut : 
Dary les Shabrina, Hasna Fadillah Sustring, Mayang Sari, Nur Baity Ulya Shabrina, dan Nurmala Zakir

Tabel 1. Aitem dan Korelasi Anti-Image

\begin{tabular}{ccc}
\hline Items & $\begin{array}{c}\text { Correlation } \\
\text { anti-image }\end{array}$ & KMO \\
\hline H1 & 0,741 & \\
H4 & 0,818 & \\
H5 & 0,783 & \\
H6 & 0,814 & \\
H7 & 0,815 & \\
H9 & 0,782 & \\
H11 & 0,640 & \\
H12 & 0,816 & \\
H13 & 0,850 & \\
H14 & 0,843 & \\
H15 & 0,612 & \\
H16 & 0,859 & \\
H17 & 0,870 & \\
H18 & 0,859 & \\
H19 & 0,762 & \\
H20 & 0,867 & \\
H21 & 0,692 & \\
H22 & 0,874 & \\
H23 & 0,860 \\
H24 & 0,909 \\
H25 & 0.801 & \\
H26 & 0,865 \\
H27 & 0,859 \\
H28 & 0,916 \\
\hline
\end{tabular}

Analisis tahap kedua yaitu mengekstraksi faktor. Berdasarkan tabel di Total Variance Explained, pada tabel component menunjukkan adanya 6 faktor yang dapat mewakili variabel. Hal itu dapat dilihat dari initial eigenvalues pada kolom total nilai yang dihasilkan dari 6 faktor yang bernilai diatas 1 yang kaidahnya ketika melakukan uji statistik eigenvalues harus lebih dari 1 . Pada kolom cumulative diperoleh sebesar $51,804 \%$ yang artinya aitem atau alat ukur kebahagiaan ini mampu menjelaskan kebahagiaan sebesar 51,804\% dan 48,196 tidak mampu menjelaskan kebahagiaan.

Ketika telah dilakukannya extraction diperoleh 6 aspek, namun ada satu aspek yang tidak memiliki aitem sebanyak 3. Berdasarkan Costello dan Osborne (2005) mengatakan bahwa dalam satu faktor harus terdapat minimal 3 aitem dan faktor yang kurang dari 3 aitem dianggap tidak stabil. Sehingga dilakukan kembali pengekstrasian dan terbentuklah 4 faktor. Dimana nilai variance untuk faktor 1 adalah sebesar 30,283, faktor 2 adalah sebesar 10,821, faktor 3 adalah 5.570 dan faktor 3 adalah 5,131.

Pada tahapan selanjutnya dilakukan adalah merotasi faktor untuk memaksimalkan pengelompokan aitem. Rotasi faktor yang digunakan pada penelitian ini menggunakan faktor loading sebesar 0,40 untuk mencegah terjadinya kesimpangan antar nilai faktor loading. Berdasarkan hal tersebut maka ditemukan 3 faktor yang mengalami cross loading yaitu aitem $\mathrm{H} 3, \mathrm{H} 8$, dan $\mathrm{H} 10$. 
Tabel 2. Matriks Komponen Terotasi

\begin{tabular}{|c|c|c|c|c|}
\hline \multirow[t]{2}{*}{ Aitem } & \multicolumn{4}{|c|}{ Komponen } \\
\hline & 1 & 2 & 3 & 4 \\
\hline Saya berusaha dan menyerahkan diri pada Tuhan terkait hasil ujian saya & .682 & & & \\
\hline Saya terus mencoba untuk memperbaiki meski berkali-kali direvisi oleh dosen & 679 & & & \\
\hline $\begin{array}{l}\text { Saya merasa mampu menyelesaikan semua tugas yang diberikan dengan tepat } \\
\text { waktu }\end{array}$ & .678 & & & \\
\hline Saya memahami diri dan masa lalu melalui perkuliahan ini & .666 & & & \\
\hline Saya tetap bersemangat, meskipun sering di tolak subjek & .635 & & & \\
\hline $\begin{array}{l}\text { Saya merasa dapat menyelesaikan pendidikan S2 ini meskipun menemui banyak } \\
\text { rintangan }\end{array}$ & .627 & & & \\
\hline $\begin{array}{l}\text { Saya menyusun rencana yang dapat membantu saya menyelesaikan perkuliahan ini } \\
\text { dengan cepat }\end{array}$ & .621 & & & \\
\hline Sejauh ini kehidupan saya menyenangkan & .587 & & & \\
\hline $\begin{array}{l}\text { Sejauh ini, saya telah mendapatkan hal-hal yang penting yang saya inginkan dalam } \\
\text { hidup saya }\end{array}$ & .569 & & & \\
\hline Saya dapat menerima masa lalu yang tidak menyenangkan selama berkuliah disini & .563 & & & \\
\hline Saya tahu apa yang harus dilakukan setelah lulus dari S2 ini & .498 & & & \\
\hline Saya bersemangat mengikuti perkuliahan meskipun harus bangun pagi setiap hari & & & & \\
\hline $\begin{array}{l}\text { Saya menjalani saja perkuliahan ini tanpa memikirkan rencana apapun dalam } \\
\text { menghadapinya }\end{array}$ & & .743 & & \\
\hline Saya jarang belajar saat akan ujian & & 690 & & \\
\hline Saya merasa kehidupan saya biasa-biasa saja & & 612 & & \\
\hline Saya baru akan berdoa ketika menghadapi kesulitan & & 608 & & \\
\hline Saya kurang bahagia meskipun telah mendapat apa yang diinginkan & & .604 & & \\
\hline Saya menghindari tugas yang dirasa sulit & & .578 & & \\
\hline Saya merasa ingin menyerah mengikuti perkuliahan S2 ini & & & 653 & \\
\hline $\begin{array}{l}\text { Saya sebenarnya masih diliputi rasa ragu tentang untuk apa saya menjalani } \\
\text { perkuliahan yang sulit di Mappro ini }\end{array}$ & & & .617 & \\
\hline Saya merasa Tuhan tidak mengabulkan doa-doa saya saat saya mengalami kesulitan & & & .536 & \\
\hline $\begin{array}{l}\text { Ketika saya menyadari melakukan kesalahan dalam menjawab soal ujian, saya selalu } \\
\text { memikirkannya }\end{array}$ & & & .462 & \\
\hline Saya merasa terganggu ketika mendapatkan jadwal kuliah di akhir pecan & & & & .719 \\
\hline Saya menghabiskan waktu dengan bermain handphonde dan menunda tugas & & & & .602 \\
\hline Saya malu jika teman-teman tahu masa lalu saya yang buruk & & & & .465 \\
\hline
\end{tabular}

Extraction Method: Principal Component Analysis.

Rotation Method: Varimax with Kaiser Normalization.

a. Rotation converged in 17 iterations.

Berdasarkan tabel diatas, diketahui bahwa pada faktor 1 memiliki 11 aitem, faktor 2 memiliki 6 aitem, faktor 3 memiliki 4 aitem, dan faktor 4 memiliki 3 aitem. Pada faktor 1 terdiri dari aitem $\mathrm{H} 1$, $\mathrm{H} 5, \mathrm{H} 6, \mathrm{H} 13, \mathrm{H} 14, \mathrm{H} 17, \mathrm{H} 2 \mathrm{O}, \mathrm{H} 24, \mathrm{H} 25, \mathrm{H} 26$ dan H28. Faktor 2 terdiri dari aitem H4, H7, H16, H22, 
,H23, H27. Pada faktor 3 terdiri dari aitem H9, H12, H18, H21. Sementara faktor 4 terdiri dari aitem H11, H15 dan H19.

Konstruk Skala Akhir

Langkah terakhir pada penelitian ini adalah penamaan faktor yang terbentuk sesuai dengan teori yang sudah ada dan dilakukan pengujian alfa cronbrach. Tabel dibawah ini adalah hasil Alpha Cronbrach pada penelitian ini :

Tabel 3. Alpha Cronbrach

\begin{tabular}{ccccc}
\hline Deskripsi & $\begin{array}{c}\text { Alpha } \\
\text { Cronbrach }\end{array}$ & N & $\begin{array}{c}\text { Corrected Total Item } \\
\text { Correleted }\end{array}$ & Keterangan \\
\hline Faktor 1 & 0,865 & 11 & Rentang dari 0,618-0,942 & - \\
Faktor 2 & 0,827 & 6 & Rentang dari 0,525- 0,684 & - \\
Faktor 3 & 0,716 & 3 & Rentang dari 0,466-0,605 & Gugur aitem :H23 \\
Faktor 4 & 0,525 & 3 & Rentang dari 0,290-0,420 & - \\
Kebahagiaan & 0,891 & 23 & Rentang dari 0,295-0,692 & Gugur aitem : H21 \\
\hline
\end{tabular}

Berdasarkan tabel di atas faktor pertama memiliki 11 aitem, berdasarkan pada konten pernyataannya maka faktor pertama dinamakan penerimaan diri dengan koefisien Alpa Cronbrach 0,865 . Hal ini menunjukkan bahwa faktor pertama memiliki nilai reliabilitas tinggi. Lalu faktor kedua terdiri dari 6 aitem dan berdasarkan pernyataan maka faktor kedua dinamakan tujuan hidup dengan koefisien Alpa Cronbrach 0,827. Hal ini menunjukkan bahwa faktor kedua memiliki nilai reliabilitas tinggi. Faktor ketiga memiliki 4 aitem dan berdasarkan pernyataan maka faktor ketiga dinamakan afeksi dengan koefisien Alpa Cronbrach 0,716. Hal ini menunjukkan bahwa faktor ketiga ini memiliki nilai reliabilitas yang tinggi. Sedangkan faktor keempat terdiri dari 3 aitem dan berdasarkan pernyataan maka faktor keempat dinamakan kepuasan hidup dengan koefisien Alpa Cronbrach 0,525. Hal ini menunjukkan bahwa faktor keempat ini memiliki nilai reliabilitas moderat.

Berdasarkan hal di atas maka gambaran hasil dari analisis faktor skala kebahagiaan secara keseluruhan memiliki nilai koefisien Alpa Cronbrach 0,891 maka skala kebahagiaan ini memiliki nilai reliabilitas dan konsistesi yang tinggi dengan hasil akhir skala sebagai berikut:

Tabel4. Hasil Akhir

\begin{tabular}{clc}
\hline \multicolumn{1}{c}{ Aspek } & \multicolumn{1}{c}{ Indikator } & Aitem \\
\hline Penerimaan Diri & Menerima setiap proses kehidupan, & $\mathrm{H} 1, \mathrm{H} 5, \mathrm{H} 6, \mathrm{H} 13, \mathrm{H} 14, \mathrm{H} 17$, \\
$\mathrm{H} 2 \mathrm{O}, \mathrm{H} 24, \mathrm{H} 25, \mathrm{H} 26, \mathrm{H} 28$
\end{tabular}


Terdapat 4 faktor yang terbentuk untuk skala kebahagiaan ini setelah dilakukan proses analisis, 4 faktor tersebut merupakan aspek yang menyusun skala kebahagiaan, adapun aspeknya yaitu penerimaan diri, tujuan hidup, afeksi, dan kepuasan hidup.

\section{Kesimpulan}

Berdasarkan skala kebahagiaan yang telah disusun oleh peneliti sebanyak 5 faktor dengan 28 aitem lalu dilakukan analisis faktor dan diperoleh hasil akhir skala kebahagiaan dengan 4 faktor yang terdiri dari 23 aitem. Jadi, terdapat 4 aitem yang tidak baik dan harus di eliminasi karena akan mempengaruhi kualitas skala ketika dianalisis.

Koefisien reliabilitas yang diperoleh sebesar 0,891 menunjukkan bahwa skala kebahagiaan ini memiliki konsistensi yang tinggi untuk mengukur kebahagiaan.

Saran

Berdasarkan penyusunan yang dilakukan oleh peneliti kelihatannya untuk peneliti lain selanjutnya yang ingin mengembangkan skala kebahagiaan harus mempertimbangkan jumlah subjek karena subjek untuk pengisian skala ini masih kurang.

\section{Daftar pustaka}

Alhaque, A. (2017). Tahun pertama mahasiswa Magister Profesi Psikologi semester pertama. Pluviophile. Akses 20 Oktober 2019 https://afadalhaque.blogspot.com/2017/02/menjadimahasiswa-mapro-psikologi-unpad.html

Al-Qarni, ‘aidh. (2004). Menjadi Paling Bahagia. Jakarta : Qisthi Press

Costello, Anna B and Osborne, Jason W. 2005. Best Practices in Exploratory Faktor Analysis: Four Recommendations for Getting the Most From Your Analysis. Practical Assessment Research and Evaluation,1(7)

HIMPSI. (2010). Kode etik psikologi Indonesia. Jakarta : Pengurus pusat HIMSI

Kusmawardhani, A. (2017). Yakin ingin jadi psikolog?. Kompassiana. Akses 20 Oktober 2019 https://www.kompasiana.com/naftalia/59f37480ff240579c41c9372/ingin-jadi-psikologsungguh-yakin

Seligman, M.E.P. (2005). Authentic happiness: Menciptakan kebahagiaan dengan psikologi positif. Penerjemah: Eva Yulia Nukman. Bandung: Mizan Pustaka. 